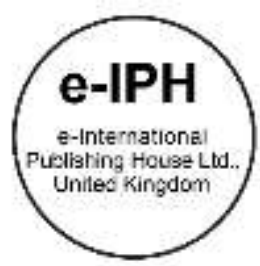

\title{
Post Office and Traditional City Square As City Linkage in Java
}

\section{R. Siti Rukayah ${ }^{1}$ Sudarmawan Juwono ${ }^{2}$ Endang Sri Susilo S ${ }^{3}$ Dhanang Respati Puguh 4}

\author{
${ }^{1}$ Architecture Department, Faculty of Engineering, \\ Universitas Diponegoro, Indonesia \\ 2 PT. Pos Indonesia, Architecture Departement, Faculty of Engineering, \\ Universitas Bung Karno, Indonesia \\ ${ }^{3}$ Marine Science Department, Faculty of Fisheries and Marine Sciences, \\ 4 History Department, Faculty of Humanities, \\ Universitas Diponegoro, Indonesia
}

tututrsiti@yahoo.com, sudarmawanjuyono@gmail.com, iiksuselo@gmail.com,_dhanang_puguh@yahoo.com Tel: 08122812825

\begin{abstract}
Dutch Colonial built a circulation path that connected cities on the North coast of Java. How was the city linkage? The methods used are historical and grounded research methods. The explanation of the city linkages has not reached the knowledge about the city layout. The postal road passed the traditional city center through the traditional square and built the post office near it to shown its existence in the traditional city center. The existence of the post office, traditional square, and postal road until now characterize the city landscape in Java so it should be a unity in the city's conservation efforts.
\end{abstract}

Keywords: Postal road; Post; Java; Conservation; Dutch.

eISSN: 2398-4287 @ 2019. The Authors. Published for AMER ABRA cE-Bs by e-International Publishing House, Ltd., UK. This is an open-access article under the CC BYNC-ND license (http://creativecommons.org/licenses/by-nc-nd/4.0/). Peer-review under responsibility of AMER (Association of Malaysian Environment-Behaviour Researchers), ABRA (Association of Behavioural Researchers on Asians) and cE-Bs (Centre for Environment-Behaviour Studies), Faculty of Architecture, Planning \& Surveying, Universiti Teknologi MARA, Malaysia.

DOI: https://doi.org/10.21834/e-bpj.v4i10.1624

\subsection{Introduction}

PT. Post office Indonesia is one of the State-Owned Enterprises in the form of Limited Liability Company (PT) whose capital or shares are at least $51 \%$, whose purpose is to pursue profit. As a company that has older age compared to the Republic of Indonesia. The Post office Indonesia has a fairly high history in building social and cultural communication in Indonesia.

In history, the Post office of Indonesia is one of the oldest state-owned enterprises in Indonesia. Its presence in the archipelago originated from the Dutch East Indies trading company (VOC) which established the Post Office on August 26, 1746, in Batavia (Jakarta) with a view to facilitating mail delivery, especially in trading activities. Until now, it can be said that the post office building is a cultural heritage building that still functions as it originally was.

As time goes by, the Post office Indonesia is now able to show its creativity in developing Indonesia's post by utilizing its network infrastructure that reaches about 24 thousand service points reaching 100 percent of districts, almost 100 percent of sub-districts and 42 percent of villages and 940 remote transmigration sites in Indonesia. Along with the development of information, communication, and technology, the Post office Indonesia network already has more than 3,800 online office and equipped electronic mobile post in several big cities. All points are chains that are connected to each other in a solid \& integrated way. The Postal Code system was created to facilitate the processing of postal items in which every inch of the country in Indonesia was accurately identified.

In the development of the world economy as today is generally influenced by several things: globalization, economic and market groups, technology, role shifting, and deregulation. The condition has had an impact on increasing traffic of goods, people and 
information between countries with a higher intensity, thanks to the support of advanced telecommunication and informatics technology. (Suhanda, n.d.) (Sudarmawan \& Rukayah, 2018)

Based on the history of urban planning, the location of the post office is at the city zero point and adjacent to the location of the traditional city square (for cities in Java) (Priyantoko, 2010) or near the city center (outside Java). (R. S. Rukayah \& Juwono, 2018) (Sudarmawan \& Rukayah, 2018). The growth of the post office can be said to be in line with the construction of the Daendels postal line in 1809-1811. The route that connects Anyer to Panarukan was built to protect cities on the North coast from attack by the British. According to (Pratiwo, 2004). In the building of this pathway, had been turned some cities into modern cities. Furthermore (Pratiwo.P.Nas, 2002) stated that the development of this pathway leads to the growth of economic activities in the cities it passes in. At present, even these economic activities are more advanced compared to other cities in the interior of Java. The benchmark of comparison according to (R. S. Rukayah, Wibowo, \& Wahyuningrum, 2015) is the development of the batik industry and tourism in the small town of Pekalongan. Many batik cities in Java, but only Pekalongan has grown into an industrial city known to foreign countries. The development of cities in Java due to the construction of postal lines can be interpreted that the Dutch colonialism had an influence on aspects of Indonesian people's lives, both economic aspects and the development of urban architecture (Suhanda, n.d.) (R. S. Rukayah \& Juwono, 2018). In connection with urban planning during the construction of the postal line, the architectural traces of the Post office buildings also provide color and morphology changes in traditional city cities in Java. (Priyantoko, 2010). The Dutch colonial period has given a positive influence on the development of urban architecture including the placement of a post office near the square / traditional city center.

The history of post office is so long, since it was established in Batavia / Jakarta in 1746 with the purpose of further guaranteeing the security of shipping documents, especially for those who trade from offices outside Java and for those who come from and go to the Netherlands. Since that time postal services have been carried out the role and function of service to the public. The uniqueness of a post office as the heritage building which is still used and operated as a post office services until today. Indeed, the incessant of social media has replaced the function of the post office as a place for sending mail. As a result, now the Post Office is more active in shipping goods. It is interesting to examine the role of the postal route, traditional city center and post office towards the connectivity of cities in Java. Post offices in Java are managed by local region and they are under the control of the division of asset management. The commercialization process is carried out by the subsidiary namely PT Pos Properti Indonesia)

The conservation efforts have been done by the government by assigning post office buildings as cultural reserves and also the appointment of the square area. The function and role of the square has shifted from the traditional concept to the modern one. Meanwhile, the function of the post office is still remained and is managed by PT Pos Indonesia

\subsection{Literature Review}

\subsection{The History of Postal Highway}

At first, physically, the road might be created to meet the "physical needs of humans", for example, to bring distance closer and open new territories. The imagination of the road, in the gaze of power, is how the road is created for the opening of new territories to be controlled or to maintain the territory that has been mastered. 1808-1811 Daendels built the Postal Highway with power imagination (Saidi, 2010). The road that was originally intended for the Dutch to defend their colonies from this British invasion was then known as the Postal Highway. Before the road was built, people delivering letters from Batavia to Semarang took 10-14 days in the dry season or 3 weeks in the rainy season. People travel for a month to travel from Batavia to Surabaya in the summer. After the Post Highway was built, letters from Batavia to Semarang only took 3-4 days by postal train which was departed twice a week. The journey from Anyer to Batavia is only 4 days. From Batavia to Surabaya it was shortened to 6 days (Toer, 2005).

At the time of postal highway, plays an important role in the development of Java island until almost 2 centuries. (Pratiwo.P.Nas, 2002). According to Plakaatboek van Nederlandsch Indie volume 14 and the Raffles map published in London in 1817 (this map is older than the Dutch maps) it can be seen that the highway starting from Banten. The difficult natural conditions faced in mountain rock in Sumedang Development difficulties were also faced when building a road connecting the cities of Semarang and Demak. Through the swampy area at that time. (Pratiwo.P.Nas, 2002)(Pratiwo, 2004)(Toer, 2005). However, the city change to a modern city appears in cities that have been traversed by this route from the past (Pratiwo.P.Nas, 2002) to the present (R. S. Rukayah et al., 2015).

From the various discussions of the postal line by experts, until now no one has discussed how the pathway contributed to the construction of post office buildings and the connection with the square as a city center in various cities in Java. This paper will contribute knowledge on how the post office, city square, and postal become a city linkage from the city to one either cities in Java.
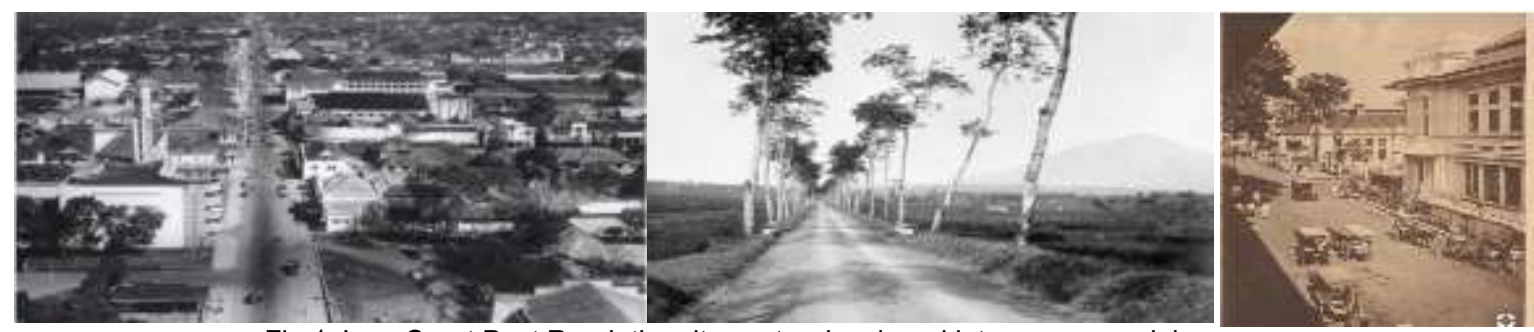

Fig.1 Java Great Post Road, the city center developed into a commercial area

(Source: kitlv.nl) 


\subsection{City Linkage and Urban Morphology}

Maki, 1964, stated that urban forms are joined together by the glue of city linkage elements, where building masses that play a role in linkage form articulation, and circulation that has given the city an image. The physical-spatial circle forms the organization of space and spatial relations. Linkage theory can describe the potential and function of regions that continue to grow. Meanwhile, (Trancik, 1986) states that linkage theory is used to read connectivity between urban spaces. In a structural environment, two or more forms of city structure are combined into one unit in their order. According to Zahnd, 1999, a city area is composed of 4 morphological structure, namely function structure, building structure, circulation structure, and plot structure. In the discussion of the urban situation using the postal route, the discussion of the structure of the city is a city circulation network. According to (Markus Zahnd, 2008) circulation structure patterned Grid, Comb, Tree, Ribbon, Ring, Radial, Mix. Several researchers have researched the ribbons pattern on the postal road through city towns on the North coast of Java (Pratiwo.P.Nas, 2002) (Pratiwo, 2004). However, discussions about what are the elements that make up or connect even form the vertices of a ribbon as a linkage system have not discussed yet.

\subsection{City Square in Java}

The old city center in Java has an open space. There are government buildings, worship buildings, markets, and other public buildings in that open space. The arrangement is based on the concept of hierarchical microcosmic with the dominance of the North-South axis, (Damayanti, 2005) (Hartono, 2005) (Handinoto, 1992). In the Islamic era, the pattern of the old city center on the north coast of Java is the core connected with the harbor area. (R. S. Rukayah, Susilo, \& Abdullah, 2018) (R. S. Rukayah, Puguh, \& Endang Sri Susilo, 2018). Government-controlled Events in the square such as government activities and religious activities (Wessing, 1992) (Talens, 1993), City morphological patterns on the North coast Java is almost the same as other Islamic cities in Java, such as Cirebon and Demak (S. Rukayah \& Malik, 2012) (S. Rukayah, Respati, \& Susilo, 2016) and the Surakarta sultanate city in the remote area of Java (Prayitno \& Qomarun, 2007) The pattern of the Islamic sultanate city in Java when referring to opinions (Muljana, 2005) could be replicated in the city model in Majapahit kingdom. MC Lain Pont. A famous architect from the Netherlands successfully described the kingdom area whose ruins of the city. But apparently, because of the lack of sensitivity to scale, the ancient city of Majapahit became too broad, (Tribinuka, 2014). Refers to the ancient capital of Majapahit and to several landmarks within the town, most of which can still be identified on site on the basis of Wardenaar's mapping (Gomperts, Haag, Carey, Kafka, \& Stutterheim, 2008). (Gomperts, Haag, \& Carey, 2010). Thus, the city square pattern in Java is a model of the city center that is sustainable with the king or sultan as the ruler and designer of the city.

Since the 18th century, with the construction of the postal line, the fortress city, the power of the Javanese king must be shared with the power of the Dutch colonial government (Damayanti, 2005) (Priyantoko, 2010) (Marihandono, 2007)

Many studies on urban centers in Java, however, are still rarely examined about the center of colonial cities in Java in the 18th century which was built to show its existence by means of its proximity to the center of indigenous government (S. Rukayah \& Malik, 2012), The Dutch colonial government demonstrated the existence of its power in the center of the newly built city by connecting it with the Postal line and building facilities such as fortress and the post office. The fortresses were built at the center of the king's power or the center of government. (Marihandono, 2007). While the post office was built in every major city that has a trade network. The post office and fortress represent the image of the new ruler who controls the activities of the local government and trade in the city.

\subsection{Traditional city patterns and modern Dutch colonialism}

The postal line was discussed more as a path that grew the economy and defense lines along the northern coast of Java. There are not many studies on this pathway that discuss the efforts to establish linkage of traditional cities by placing the post office right in the center of the traditional city and located near the square/city square. The existence of the post office near the square became the zero point of the city. At first, the distance between the city center was $30 \mathrm{~km}$ (Toer, 2005), the ideal distance for horse riders carrying goods/posts. besides the post office, there is also a horse turnover in the square. New knowledge about the post office as a city linkage places conservation effort on 3 interrelated matters, namely, the postal line, the city center square and post office into a whole unit forming city linkage in Java. The post office contributed to the establishment of a city center in Java with additional colonial characters. Placement of the post office in the 18th century in the traditional city center in Java formed a network that connected cities in Java and formed the morphology of traditional which shows the power of sharing between the local government and Colonial. The results of the old city center design had the same pattern in several cities.

\subsection{Methodology}

This method is the historical method (Kuntowijoyo, 1994) and grounded research. The data collection take from various sources of history and case studies. The historical data, ancient photos, and ancient maps are obtained from the Dutch library collection. The analysis is conducted by using readings through ancient images (Pole, 2004). The meaning of the city analyzed through reading ancient cities (Smith, 2007) and through the idea of designing modern cities in Indonesia (Coté, 2014). By using the mix methods, the effort to uncover the history of the post, the post of the post and the square will get accurate data. The analysis based on politics and economics on urban design is also done based on opinions from (Cuthbert, 2008) and techniques in urban design (Moughtin, 1999). An effort to analyze the technique will reveal the political and economic aspects of the pattern and model of urban development 


\subsection{Findings}

\subsection{Post Office and Postal Highway}

The purpose of the construction of Postal highways to facilitate communication between Dutch controlled areas along Java Island and as a fortress on the North Coast of Java Island. The postal road greatly changed the configuration of Java cities space, which was previously oriented to the axis between the kingdoms in the south area and the trading towns on the north coast. The Postal Road increases the chances of a new settlement rise, new markets and trading places emerge. The corridor of Post Road to the city center has turned into a commercial area, such as in Bandung and Semarang. The development of land transportation routes encouraged the growth of postal services and the establishment of post offices in several major cities in Java. The post office becomes the node and the place to stop post and goods transportation. The location of the post office planning is near the city center because the city center acts as the center of government, the religious center and the center of economic activity. the location of post offices is almost in every city on Java, especially on the north coast of Java. The post office was found in several cities located adjacent to the town square. Here is a list of the position of the post office located on the North side of the square.

Table 1. The location of post Office in the north side of the city center square

\begin{tabular}{|l|l|l|l|l|l|}
\multirow{2}{*}{ Kota } & \multicolumn{5}{|c|}{ Bangunan di sekitar Alun-alun } \\
\cline { 2 - 6 } & \multicolumn{1}{|c|}{ Pemerintahan } & Pasar & \multicolumn{1}{|c|}{ Gereja } & Stasiun & $\begin{array}{c}\text { Kantor } \\
\text { Pos }\end{array}$ \\
\hline Batavia (Stadhuisplein) & $\begin{array}{l}\text { Selatan } \\
\text { (Balaikota) }\end{array}$ & 0 & $\begin{array}{l}\text { Barat (Bekas } \\
\text { Gereja) }\end{array}$ & Selatan & Utara \\
\hline Batavia (Koningsplein) & $\begin{array}{l}\text { Selatan } \\
\text { (Balaikota) }\end{array}$ & Timur & Timur & Timur & 0 \\
\hline Semarang & 0 & Timur & 0 & 0 & Utara \\
\hline Surabaya (Ketabang) & Utara (Balaikota) & 0 & 0 & 0 & 0 \\
\hline Surabaya (Kepanjen) & Timur (Balaikota) & Timur & Utara & 0 & Utara \\
\hline
\end{tabular}

(Source: Priyantoko, 2010)

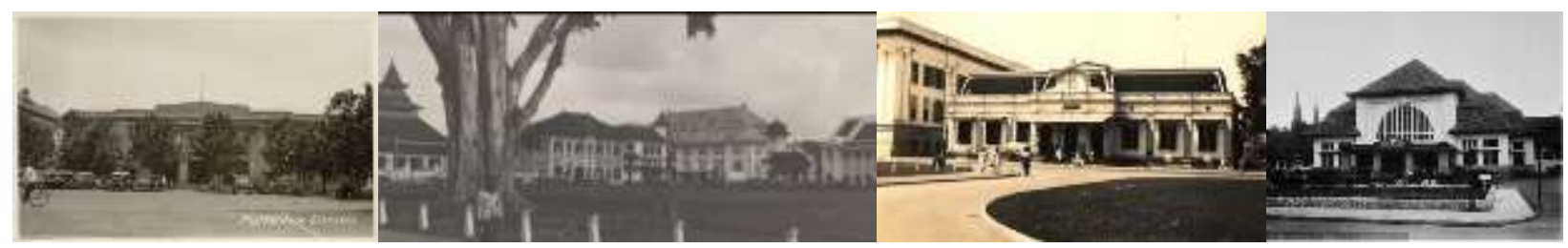

The post office Jakarta

The post office Bandung

The post office Semarang

The post office Surabaya

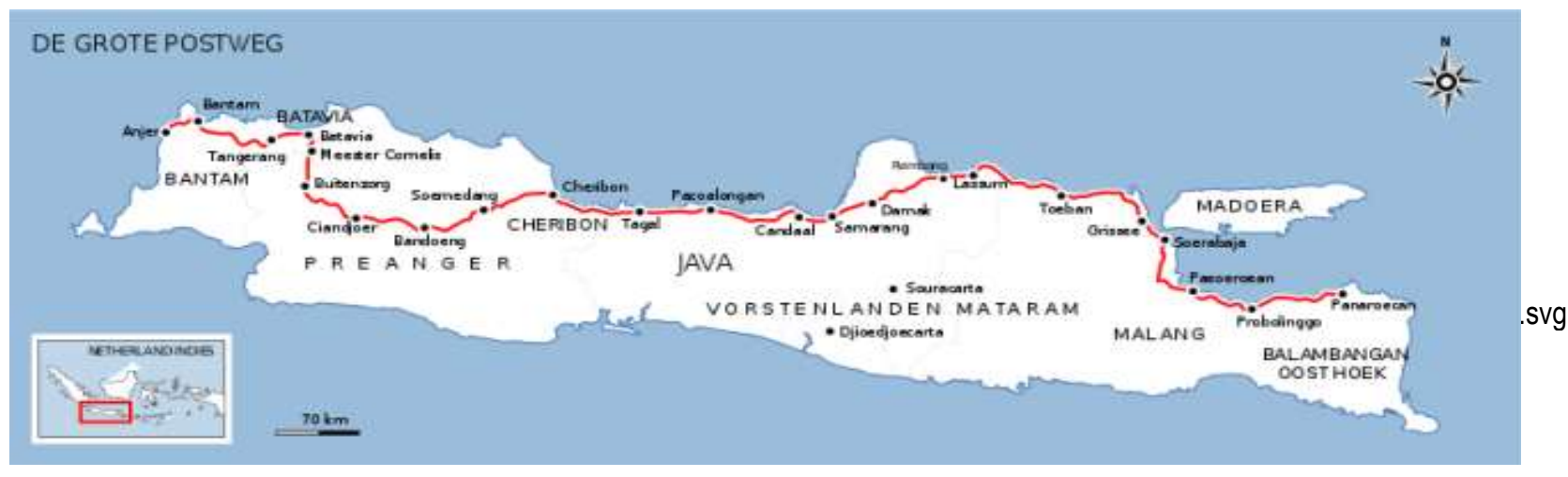

Fig.2 Java Great Post Road

(Source: https://id.wikipedia.org/wiki/Berkas:Java_Great_Post_Road.svg)

\subsection{The Post Office Building}

The cities of Jakarta, Semarang, Bandung, and Surabaya were used as case studies of the location of post offices located connected in the Postal line, near the fort and the traditional city center/square. The post office in the four cities is unique as the first post office (Jakarta), the second post office (Semarang). Meanwhile, post offices in Jakarta, Semarang, Bandung, and Surabaya are unique because the location of the post office is right on the square. 


\subsubsection{Jakarta Post Office}

The first post office in Indonesia established in Batavia (now Jakarta) on August 26, 1746. After the Batavia Post Office, the Semarang Post Office was established four years later to hold regular postal relations between the two places and to expedite the delivery. The Batavia post office is in the old city area of Jakarta. The area in the past was still a fortress. Based on the history of the old city of Jakarta, the colonial Jakarta fortress area was built side by side with the traditional city center or on the West side of the square. However, finally, the colonial city expanded to the Westside and covered the traditional city area.

\subsubsection{Semarang Post Office}

The Semarang Post Office was established four years after the establishment of the Batavia post office (1750). The presence of this post office was inseparable from the role of the 27 th Dutch Governor-General, GW Baron van Imhoff who ordered the construction of a post office in Semarang after the construction of a post office in Batavia. The Semarang Post Office is one of the old buildings that are still left until now in the Postal Highway (Jalan Pemuda). The postal road development divides part of the old square Semarang. at a later stage, the road developed into a center for trade and settlements for upper-class Europeans and on the northern side adjacent to the square in the post office. The office establishment was close to the square and the old city fort of Semarang. This area is the zeropoint marker of the city of Semarang.

\subsubsection{Bandung Post Office}

The Bandung Post Office was built from 1928 until 1931. This building located at postal highway (Jalan Asia Afrika) near to the square and still stands firmly to this day. At first, this place was only a letter carriage stop. Then, this small post office was built in 1863 before finally being renovated in 1928. The architect of Bandung Post Office is the Dutch institute J. Van Gendt. From 1928 until now the building of the Bandung Post Office has never changed.

\subsubsection{Surabaya Post Office}

In the past, the Surabaya Post Office was known as the Regentstraat because until 1881 there were official houses of the Adipate (regent) there. Before becoming a post office building, the building was actually a residence for the Regent of Surabaya which was built in early 1800. After several renovations and switch over building function, now the building has a function back at the post office until now.

According to the several findings above, the location of the post office is in the colonial city/fort area adjacent to the center of the city of indigenous government. The postal line passed through the center of indigenous government/square. There are allegations that the construction of the postal route through the square is an attempt to facilitate the colonial government's supervision of the indigenous government. However, the development towards modernization and growth of the region has become a commercial area that should be expected that there are other reasons, namely for the purpose of regional and economic development.

\subsection{Discussion}

The postal route that connects traditional cities in Java through the city center of government. The postal line is right near the square. In coastal cities, such as Jakarta, Semarang, and Surabaya this route is also the route to the city wall/fortress. The post route becomes City linkage which connects the centers of indigenous government and fort. This urban form network is in the form of a ribbon. The city linkage elements are the city center, the post office, and the postal road. The development of land transportation has fostered the development of postal services, which eventually built post offices in several of these cities. Post office buildings play a role in linkage to form articulations, and circulation that occurs has given the city an image.

Fortresses, squares and post offices form a linkage that is structured with two or more forms of city structure combined into one unit in its order. These elements have the same pattern in each city and form a node from the postal path as a ribbon.

With the Building of the postal route through the native city center, the concept of structuring cities in Java changed. The concept of city center arrangement in the pre-colonial era was based on the concept of hierarchical microcosmic with the dominance of the NorthSouth axis has changed. The existence of the post line cuts the North axis which connects the square with the port of call. However, the existence of the postal path does not change the location of the mosque, the function, and location of Square, Palace, and Market, in. History of urban planning, construction of postal lines and colonial government centers/fortresses near the square along with government facilities, housing luxury/villa and post office show the efforts of the Dutch government to show its existence. The power of the indigenous government must be shared with the power of the Dutch colonial government.

It can be concluded that the existence of a post near the square proves that in its development cities in Java did not stop with traditional concepts. The postal route has changed parts of Java. The city center square experienced a change of power from indigenous rulers to coexist with the Dutch East Indies colonial rulers. These changes had an impact on urban development which followed the thinking design of the colonial government.

\subsection{Conclusion \& Recommendations}

The existence of post office buildings is still operating today in the city of large cities, especially on the island of Java. Based on the individual building, the post office buildings have been registered in cultural heritage buildings. However, collectively, the post office buildings including the postal road, fort and Traditional city center that connects them are not yet included in the list of cultural heritage. 
The post as a forming element of cities in Java with the presence of a post office in the center of the city and marking the zero point of the city is very important becoming a priority for conservation.

As an old building with the distinctive architectural style, the combination of the concept of an architectural style tour, the building office needs to be conserved in the right way because it has a high historical value. The conservation is activity related to physical or building elements (historic) interventions to coexist to ensure the structural integrity of continuity. The special value of conservation at the post office is the value of the sustainability of the function of the post office as a freight forwarding office that still continues today.

\subsection{Acknowledgement}

Thanks to International, Strategic Research Engineering Faculty that focus on heritage building, Basic Research from Architecture Department that focus on traditional city center, Research Publication 2018, and Higher Education Applied Research 2018 DIKTI that gave funding for this research. The gratitude also goes to the Post Office for the study of architecture and heritage that have been pleased to provide data in the field.

\section{References}

Coté, J. (2014). Thomas Karsten's Indonesia: Modernity and the end of Europe, 1914-1945. Bijdragen Tot de Taal-, Land- En Volkenkunde, 170(1), 66-98. https://doi.org/10.1163/22134379-17001004

Cuthbert, A. R. (2008). The Form of Cities: Political Economy and Urban Design. The Form of Cities: Political Economy and Urban Design. https://doi.org/10.1002/9780470774915

Damayanti, R. (2005). Kawasan "Pusat Kota" Dalam Perkembangan Sejarah Perkotaan di Jawa, 33(1), 34-42.

Gomperts, A., Haag, A., \& Carey, P. (2010). Rediscovering the royal capital of Majapahit, 2(53), 12-13.

Gomperts, A., Haag, A., Carey, P., Kafka, F., \& Stutterheim, W. F. (2008). Stutterheim ' s enigma the mystery of his mapping of the Majapahit Kraton at Trowulan in $1941,4,411-430$

Handinoto. (1992). Alun-alun sebagai identitas kota jawa, dulu dan sekarang ., (September), 1-15.

Hartono, S. (2005). Alun-alun Dan Revitalisasi Identitas Kota Tuban. Dimensi Teknik Arsitektur, 33(No1), 131-1.

Kuntowijoyo. (1994). Metodologi Sejarah. Tiara Wacana Yogya.

Marihandono, D. (2007). Perubahan peran dan fungsi benteng dalam tata ruang kota.

Markus Zahnd. (2008). Model baru perancangan kota yang kontekstual. Kanisius.

Moughtin, C. (1999). Urban Design Methode and techniques. Architectural Press.

Muljana, S. (2005). Runtuhnya Kerajaan Hindu-Jawa dan Timbulnya Negara-negara Islam di Nusantara. Yogyakarta: LkiS.

Pole, C. J. (2004). Seeing Is Believing? Approaches to Edited By. Studies in Qualitative Methodology Volume 7 (Vol. 7 ).

Pratiwo.P.Nas. (2002). Java and De Groote Postweg, La Grande Route, the Great Mail Road, Jalan Raya Pos, 158, 707-725.

Pratiwo. (2004). The City Planning of Semarang 1900-1970. (pp. 1-18). Surabaya.

Prayitno, B., \& Qomarun, Q. (2007). Morfologi Kota Solo (Tahun 1500-2000). DIMENSI (Jurnal Teknik Arsitektur), 35(1), pp.80-87.

https://doi.org/10.9744/dimensi.35.1.pp.80-87

Priyantoko, R. Y. (2010). Alun-alun di Pusat Kota Gementee di Pesisir Utara Jawa Pada Awal Abad XX Masehi. Universitas Indonesia.

Rukayah, R. S., \& Juwono, S. (2018). Arsitektur dan Desain Kota Hibrida Pada Kantor Pos Dan Alun-alun di Medan. Tata Loka, 20 No 3(Agustus 2018), 317-330.

Rukayah, R. S., Puguh, D. R., \& Endang Sri Susilo. (2018). Local Wisdom of The Native Settlement as A Main Gate in The Northern Axis of Javanese City Center In Semarang Local Wisdom of The Native Settlement as A Main Gate in The Northern Axis of Javanese City Center In Semarang. IOP Conference Series: Earth and Environmental Science PAPER.

Rukayah, R. S., Susilo, E. S., \& Abdullah, M. (2018). Exploring the Position of Old Semarang Sea Port: Based on Javanese City Pattern. In 3rd International Conference on Tropical and Coastal Region Eco Development 2017 (pp. 0-8). IOP Conference Series: Earth and Environmental Science PAPER

Rukayah, R. S., Wibowo, A. A., \& Wahyuningrum, S. H. (2015). Public Participation in Branding Road Corridor as Shopping Window or Batik Industry at Pekalongan. Procedia - Social and Behavioral Sciences, 168, 76-86. https://doi.org/10.1016/j.sbspro.2014.10.212

Rukayah, S., \& Malik, A. (2012). Between Colonial, Moslem, and Post-Independence Era, Which Layer of Urban Patterns should be Conserved? Procedia - Social and Behavioral Sciences, 68, 775-789. https://doi.org/10.1016/j.sbspro.2012.12.266 
Rukayah, S., Respati, P. D., \& Susilo, S. E. S. (2016). Morphology of Traditional City Center in Semarang: Towards Adaptive reuse in urban heritage. EnvironmentBehaviour Proceedings Journal, 1(4), 109-118. https://doi.org/10.21834/e-bpj.v144.91

Saidi, A. I. (2010). Jalan Raya Sebagai Desain Kebudayaan. Journal Sosioteknologi, Edisi 19 T(April), 769-781.

Smith, M. E. (2007). Form and Meaning in the Earliest Cities: A New Approach to Ancient Urban Planning (Vol. 6). https://doi.org/10.1177/1538513206293713 Sudarmawan, Y., \& Rukayah, S. (2018). Bangunan Heritage Kantor Pos Medan.

Suhanda, R. (n.d.). Penerapan Gaya Arsitektur Transisi / Kolonial pada Bangunan Kantor Pos Besar Medan.

Talens, J. (1993). Ritual Power: The Installation of a King in Banten, 149, 333-355.

Toer, P. A. (2005). Jalan Raya Pos, Jalan Daendels. Lentera Dipantara.

Trancik, R. (1986). Finding Lost Space; Theories of Urban Design. New York: Van Nostrand Reinhold Company.

Tribinuka, T. (2014). Rekonstruksi Arsitektur Kerajaan Majapahit dari Relief, Artefak dan Situs Bersejarah, 19-24.

Wessing, R. (1992). A Tiger in The Heart: The Javanese Rampok Macan, 148, 287-308. 